\title{
Risk assessment after acute upper gastrointestinal haemorrhage
}

T A Rockall, R F A Logan, H B Devlin, T C Northfield, and the steering committee and members of the National Audit of Acute Upper Gastrointestinal Haemorrhage

\begin{abstract}
The aim of this study was to establish the relative importance of risk factors for mortality after acute upper gastrointestinal haemorrhage, and to formulate a simple numerical scoring system that categorises patients by risk. A prospective, unselected, multicentre, population based study was undertaken using standardised questionnaires in two phases one year apart. A total of 4185 cases of acute upper gastrointestinal haemorrhage over the age of 16 identified over a four month period in 1993 and 1625 cases identified subsequently over a three month period in 1994 were included in the study. It was found that age, shock, comorbidity, diagnosis, major stigmata of recent haemorrhage, and rebleeding are all independent predictors of mortality when assessed using multiple logistic regression. A numerical score using these parameters has been developed that closely follows the predictions generated by logistical regression equations. Haemoglobin, sex, presentation (other than shock), and drug therapy (non-steroidal anti-inflammatory drugs and anticoagulants) are not represented in the final model. When tested for general applicability in a second population, the scoring system was found to reproducibly predict mortality in each risk category. In conclusion, a simple numerical score can be used to categorise patients presenting with acute upper gastrointestinal haemorrhage by risk of death. This score can be used to determine case mix when comparing outcomes in audit and research and to calculate risk standardised mortality. In addition, this risk score can identify $15 \%$ of all cases with acute upper gastrointestinal haemorrhage at the time of presentation and $26 \%$ of cases after endoscopy who are at low risk of rebleeding and negligible risk of death and who might therefore be considered for early discharge or outpatient treatment with consequent resource savings.

(Gut 1996; 38: 316-321)
\end{abstract}

Keywords: gastrointestinal haemorrhage, risk assessment.

Correspondence to:

Mr T Rockall, The Surgical Epidemiology and Audit Unit, The Royal College of Surgeons of England, 35-43 Lincoln's Inn Fields, London WC2A 3PN.

Accepted for publication

7 September 1995
Acute upper gastrointestinal haemorrhage is a common medical emergency with an incidence in England of approximately 100 per 100000 adults per year and a mortality among unselected cases in the region of $14 \% .^{1}$ The important factors influencing the outcome of acute upper gastrointestinal haemorrhage have been the focus of much research and debate since the 1940s but, although the risk factors associated with both rebleeding and death are well known, different researchers have put a different emphasis on each of these according to their experiences. ${ }^{2-16}$ Age, comorbidity, shock, diagnosis, admission haemoglobin values, presentation, ulcer size, stigmata of recent haemorrhage, and blood transfusion requirements have all been described as significant risk factors for further haemorrhage and death. Further haemorrhage has been consistently described as the most important risk factor for mortality. It is generally accepted that the risk of rebleeding and death is related to many factors, which are not entirely independent of each other.

While previous studies have served to indicate which variables are important in determining the risk of rebleeding and death, few attempts have been made to devise a simple and therefore clinically useful risk scoring system that makes use of readily available clinical information to categorise patients by risk. We have used a large uniform database to analyse the risk factors for mortality and we have used the analysis to construct a simple numerical risk scoring system. The primary purpose of this score is to allow case mix assessment for comparative audit. An understanding of the risk associated with any particular patient is an important initial step in the management process. Most cases of acute upper gastrointestinal haemorrhage are treated by junior staff in the setting of busy casualty departments and a simple scoring system may be a useful aid to the clinical judgement of risk, especially as there is evidence of considerable disagreement as to what the important prognostic factors are, even within the British Society of Gastroenterology. ${ }^{17}$ The development of treatment protocols and the selection of patients for clinical trials are other areas where a risk index might be of benefit.

\section{Methods}

The data presented were collected as part of a national audit of the management and outcome of acute upper gastrointestinal haemorrhage. Four health regions in England (North West Thames, South West Thames, Trent, and the West Midlands) were recruited to this prospective study, undertaken under the auspices of the British Society of Gastroenterology, the Royal College of Surgeons of England, the Royal College of Physicians of 
TABLE I Factors analysed in relation to rebleeding and mortality with odds ratios and $95 \%$ confidence intervals

\begin{tabular}{|c|c|c|c|c|c|c|c|c|c|}
\hline \multirow[b]{2}{*}{ Variable } & \multirow[b]{2}{*}{ Type of data } & \multirow[b]{2}{*}{ Categorisation } & \multirow[b]{2}{*}{ Cases } & \multicolumn{2}{|l|}{ Rebleed } & \multicolumn{2}{|l|}{ Dead } & \multirow[b]{2}{*}{ Odds } & \multirow[b]{2}{*}{$95 \% C I$} \\
\hline & & & & No & $\%$ & No & $\%$ & & \\
\hline All cases & & & 4185 & $\begin{array}{l}643 / 4119 \\
\quad(66 \text { missing) }\end{array}$ & $15 \cdot 6$ & $\begin{array}{l}585 / 4142 \\
\quad(43 \text { missing) }\end{array}$ & $14 \cdot 1$ & & \\
\hline Age & Continuous & $\begin{array}{l}<60 \\
60-79 \\
>=80\end{array}$ & & $\begin{array}{l}151 / 1290 \\
291 / 1741 \\
201 / 1088\end{array}$ & $\begin{array}{l}11 \cdot 7 \\
16 \cdot 7 \\
18 \cdot 5\end{array}$ & $\begin{array}{r}74 / 1294 \\
255 / 1754 \\
256 / 1094\end{array}$ & $\begin{array}{r}5 \cdot 7 \\
14 \cdot 5 \\
23 \cdot 4\end{array}$ & $\begin{array}{l}\text { Reference } \\
2 \cdot 80 \\
5.04\end{array}$ & $\begin{array}{l}2.14 \text { to } 3.67 \\
3.83 \text { to } 6.62\end{array}$ \\
\hline$\underset{\quad \text { Sex }}{4 \text { missing })}$ & Categorical & Male & 2376 & $379 / 2366$ & 16.0 & $313 / 2376$ & $13 \cdot 2$ & Reference & \\
\hline Shock & Ordinal & No shock & 2897 & $\begin{array}{l}20301 / 49 \\
330\end{array}$ & $\begin{array}{l}15 \cdot 0 \\
11.4\end{array}$ & $\begin{array}{l}288 / 1762 \\
288\end{array}$ & $\begin{array}{r}15.4 \\
9.9\end{array}$ & $\begin{array}{l}1 \cdot 20 \\
\text { Reference }\end{array}$ & 1.01 to 1.43 \\
\hline (74 missing) & & $\begin{array}{l}\text { Tachycardia } \\
\mathrm{BP}<100 \\
\mathrm{BP}<70 \\
\mathrm{BP}<50\end{array}$ & $\begin{array}{r}687 \\
347 \\
60 \\
34\end{array}$ & $\begin{array}{r}164 \\
94 \\
30 \\
15\end{array}$ & $\begin{array}{l}23 \cdot 9 \\
27 \cdot 1 \\
50 \cdot 0 \\
44 \cdot 0\end{array}$ & $\begin{array}{r}134 \\
95 \\
28 \\
27\end{array}$ & $\begin{array}{l}19 \cdot 3 \\
27 \cdot 1 \\
45 \cdot 9 \\
71 \cdot 1\end{array}$ & $\begin{array}{c}2 \cdot 17 \\
3 \cdot 37 \\
7 \cdot 70 \\
22 \cdot 3\end{array}$ & $\begin{array}{c}1.73 \text { to } 2.71 \\
2.58 \text { to } 4.39 \\
4.59 \text { to } 12.9 \\
10.9 \text { to } 45.4\end{array}$ \\
\hline Haemoglobin & Continuous & $\mathrm{Hb}>=10$ & 2554 & 299 & 11.7 & $275 / 2554$ & $10 \cdot 8$ & Reference & \\
\hline NSAID & Categorical & $\begin{array}{l}\mathrm{Hb}<10 \\
\text { No } \\
\text { Yes }\end{array}$ & 1362 & $\begin{array}{l}314 \\
423 / 2820 \\
220 / 1299\end{array}$ & $\begin{array}{l}23 \cdot 3 \\
15 \cdot 0 \\
16 \cdot 9\end{array}$ & $\begin{array}{l}258 / 1362 \\
417 / 2834 \\
168 / 1308\end{array}$ & $\begin{array}{l}18 \cdot 9 \\
14 \cdot 7 \\
12 \cdot 8\end{array}$ & $\begin{array}{l}1.94 \\
\text { Reference } \\
0.85\end{array}$ & 1.61 to 2.33 \\
\hline Anticoagulants & Categorical & $\begin{array}{l}\text { No } \\
\text { Yes }\end{array}$ & $\begin{array}{r}3864 \\
278\end{array}$ & $\begin{array}{c}595 / 3841 \\
48 / 278\end{array}$ & $\begin{array}{l}15 \cdot 5 \\
17 \cdot 3\end{array}$ & $\begin{array}{c}536 / 3864 \\
49 / 278\end{array}$ & $\begin{array}{l}13 \cdot 9 \\
17 \cdot 6\end{array}$ & $\begin{array}{l}\text { Reference } \\
1.33\end{array}$ & 0.96 to 1.83 \\
\hline SRH & $\begin{array}{l}\text { Categorical } \\
n=3047\end{array}$ & None & $\begin{array}{l}1976 \\
1078\end{array}$ & $\begin{array}{l}178 \\
298\end{array}$ & $\begin{array}{r}9 \cdot 0 \\
27 \cdot 8\end{array}$ & $\begin{array}{l}103 \\
193\end{array}$ & $\begin{array}{r}5 \cdot 2 \\
17 \cdot 9\end{array}$ & $\begin{array}{l}\text { Reference } \\
3.97\end{array}$ & 3.08 to $5 \cdot 10$ \\
\hline $\begin{array}{l}\text { Further haemorrhage } \\
\text { (62 missing) }\end{array}$ & Categorical & $\begin{array}{l}\text { No } \\
\text { Yes }\end{array}$ & $\begin{array}{r}3387 \\
730\end{array}$ & $\begin{array}{l}- \\
-\end{array}$ & & $\begin{array}{l}293 \\
272\end{array}$ & $\begin{array}{r}8 \cdot 7 \\
37 \cdot 3\end{array}$ & $\begin{array}{l}\text { Reference } \\
6.24\end{array}$ & $5 \cdot 15$ to $7 \cdot 56$ \\
\hline $\begin{array}{l}\text { SRH } \\
\text { (peptic ulcer } \\
\text { group only) } \\
\mathrm{n}=1300\end{array}$ & Categorical & $\begin{array}{l}\text { None } \\
\text { Blood in UGIT } \\
\text { Adherent clot } \\
\text { Visible vessel } \\
\text { Spurting vessel } \\
\text { Dark spot }\end{array}$ & & $\begin{array}{c}66 / 674 \\
103 / 316 \\
79 / 238 \\
22 / 97 \\
9 / 34 \\
17 / 115\end{array}$ & $\begin{array}{r}9 \cdot 8 \\
32 \cdot 6 \\
33 \cdot 2 \\
22 \cdot 7 \\
26 \cdot 5 \\
14 \cdot 8\end{array}$ & $\begin{array}{c}25 / 674 \\
68 / 321 \\
39 / 240 \\
12 / 97 \\
6 / 35 \\
11 / 117\end{array}$ & $\begin{array}{r}3 \cdot 7 \\
21 \cdot 2 \\
16 \cdot 3 \\
12 \cdot 3 \\
17 \cdot 1 \\
9 \cdot 4\end{array}$ & $\begin{array}{l}\text { Reference } \\
6.98 \\
5.04 \\
3.66 \\
5 \cdot 37 \\
2.69\end{array}$ & $\begin{array}{l}4.31 \text { to } 11.3 \\
2.98 \text { to } 8.53 \\
1.78 \text { to } 7.56 \\
2.05 \text { to } 14.1 \\
1.29 \text { to } 5.64\end{array}$ \\
\hline Diagnosis & Categorical & $\begin{array}{l}\text { None made } \\
\text { Peptic ulcer } \\
\text { Malignancy } \\
\text { Varices } \\
\text { Mallory-Weiss } \\
\text { Erosive disease } \\
\text { Oesophagitis } \\
\text { Other }\end{array}$ & $\begin{array}{r}1014 \\
1450 \\
155 \\
180 \\
214 \\
447 \\
429 \\
253\end{array}$ & $\begin{array}{r}125 \\
267 \\
47 \\
67 \\
8 \\
36 \\
37 \\
56\end{array}$ & $\begin{array}{r}12 \cdot 5 \\
18 \cdot 5 \\
29 \cdot 7 \\
37 \cdot 0 \\
3 \cdot 7 \\
8 \cdot 1 \\
8 \cdot 6 \\
22 \cdot 8\end{array}$ & $\begin{array}{r}200 \\
170 \\
58 \\
41 \\
6 \\
29 \\
35 \\
46\end{array}$ & $\begin{array}{r}19 \cdot 7 \\
11 \cdot 7 \\
37 \cdot 4 \\
22 \cdot 8 \\
2 \cdot 8 \\
6 \cdot 5 \\
8 \cdot 2 \\
18 \cdot 2\end{array}$ & $\begin{array}{l}1.75 \\
0.73 \\
3.93 \\
1.85 \\
0.17 \\
0.39 \\
0.51 \\
1.38\end{array}$ & $\begin{array}{l}1.45 \text { to } 2.11 \\
0.60 \text { to } 0.88 \\
2.80 \text { to } 5.50 \\
1.29 \text { to } 2.66 \\
0.07 \text { to } 0.38 \\
0.27 \text { to } 0.58 \\
0.36 \text { to } 0.73 \\
0.99 \text { to } 1.93\end{array}$ \\
\hline Comorbidity & Categorical & $\begin{array}{l}\text { None } \\
\text { Cardiac failure } \\
\text { Ischaemic heart disease } \\
\text { Asthma } \\
\text { COAD } \\
\text { Diabetes mellitus } \\
\text { Rheumatoid arthritis } \\
\text { Liver failure } \\
\text { Renal failure } \\
\text { Disseminated malignancy } \\
\text { Other } \\
\text { Pneumonia } \\
\text { Dementia } \\
\text { Recent major operation } \\
\text { Malignancy } \\
\text { CVATIA } \\
\text { Haematological malignancy } \\
\text { Hypertension } \\
\text { Trauma/burns } \\
\text { Other cardiac disease } \\
\text { Major sepsis } \\
\text { Other liver disease }\end{array}$ & $\begin{array}{r}1653 \\
378 \\
659 \\
136 \\
280 \\
277 \\
168 \\
178 \\
123 \\
172 \\
463 \\
88 \\
176 \\
120 \\
119 \\
253 \\
109 \\
179 \\
62 \\
141 \\
42 \\
69\end{array}$ & $\begin{array}{r}184 \\
84 \\
107 \\
18 \\
48 \\
43 \\
32 \\
61 \\
29 \\
53 \\
83 \\
12 \\
22 \\
24 \\
27 \\
32 \\
28 \\
18 \\
4 \\
20 \\
6 \\
14\end{array}$ & $\begin{array}{l}11 \cdot 2 \\
22 \cdot 6 \\
16 \cdot 5 \\
13 \cdot 3 \\
17 \cdot 6 \\
15 \cdot 9 \\
19 \cdot 0 \\
35 \cdot 5 \\
24 \cdot 4 \\
30 \cdot 0 \\
18 \cdot 0 \\
14 \cdot 1 \\
12 \cdot 5 \\
20 \cdot 5 \\
23 \cdot 7 \\
13 \cdot 1 \\
25 \cdot 7 \\
10 \cdot 2 \\
6 \cdot 9 \\
14 \cdot 5 \\
14 \cdot 6 \\
23 \cdot 3\end{array}$ & $\begin{array}{r}73 \\
129 \\
125 \\
19 \\
67 \\
62 \\
33 \\
68 \\
56 \\
89 \\
78 \\
30 \\
28 \\
27 \\
33 \\
54 \\
30 \\
19 \\
17 \\
20 \\
13 \\
5\end{array}$ & $\begin{array}{r}4 \cdot 4 \\
34 \cdot 1 \\
19 \cdot 0 \\
14 \cdot 0 \\
23 \cdot 9 \\
22 \cdot 4 \\
19 \cdot 6 \\
38 \cdot 2 \\
45 \cdot 5 \\
51 \cdot 7 \\
16 \cdot 8 \\
34 \cdot 1 \\
15 \cdot 9 \\
22 \cdot 5 \\
27 \cdot 7 \\
21 \cdot 3 \\
27 \cdot 5 \\
10 \cdot 6 \\
27 \cdot 4 \\
14 \cdot 2 \\
31 \cdot 0 \\
7 \cdot 2\end{array}$ & $\begin{array}{c}\text { Reference } \\
7 \cdot 73 \\
4 \cdot 30 \\
3 \cdot 16 \\
5 \cdot 42 \\
5 \cdot 07 \\
4 \cdot 45 \\
8 \cdot 65 \\
10 \cdot 3 \\
11 \cdot 7 \\
3 \cdot 81 \\
7 \cdot 72 \\
3 \cdot 60 \\
5 \cdot 09 \\
6 \cdot 28 \\
4 \cdot 83 \\
6 \cdot 23 \\
2 \cdot 40 \\
6 \cdot 21 \\
3 \cdot 21 \\
7 \cdot 01 \\
1.64\end{array}$ & 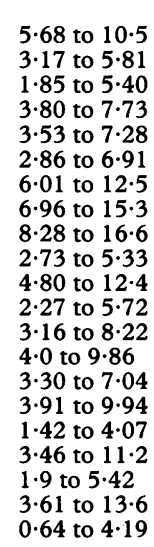 \\
\hline
\end{tabular}

$\mathrm{SRH}=$ stigmata of recent haemorrhage, $\mathrm{UGIT}=$ upper gastrointestinal tract, $\mathrm{COAD}=$ chronic obstructive airway disease, $\mathrm{CVA} / \mathrm{TIA}=\mathrm{cerebrovascular}$ accident transient ischaemic attack.

London, and the Association of Surgeons of Great Britain and Ireland. Seventy four 'acute' hospitals participated in the initial audit.

A lead consultant at each site (usually a member of the British Society of Gastroenterology) represented the project locally. The identification of subjects and administration of the questionnaire was undertaken by an audit coordinator at each hospital. Patients were identified daily in the accident and emergency department, the wards, the endoscopy unit, the operating theatre, and from blood transfusion records and admission data. The questionnaire was generally completed by medical staff and the audit coordinator was then responsible for checking and returning a completed questionnaire for each patient correctly identified. The data collected incorporated patient details including known risk factors, treatment including the use of endoscopy, endoscopic findings, details of surgical involvement, diagnosis, complications, and mortality. Data were entered into a computer database using a validated optical scanning device. ${ }^{1819}$

The risk scoring system was validated using data collected during the second phase of the national audit in 1994, which used an identical methodology at 45 'acute' hospitals from three health regions over a period of three months.

\section{Statistical methods}

Multiple logistic regression analysis ${ }^{20}$ was undertaken using SPSS computer software. ${ }^{21}$ Continuous variables were categorised to avoid multiplicative errors and variables with more than two categories were recorded using an appropriate indicator variable coding scheme. Variables were entered into the initial models if the crude odds ratios were significantly different from 1. The models were developed using a forward stepwise selection procedure. A variable was included at each step if the score statistics was less than 0.05 and was removed if 
TABLE II Significant predictor variables for mortality

\begin{tabular}{|c|c|c|c|c|c|c|c|c|}
\hline \multirow[b]{2}{*}{ Variable } & \multicolumn{4}{|c|}{ Initial model } & \multicolumn{4}{|c|}{ Complete model } \\
\hline & $b$ & $S E$ & Significance & $\operatorname{Exp}(B)$ & $b$ & $S E$ & Significance & $\operatorname{Exp}(B)$ \\
\hline \multicolumn{9}{|l|}{ Age } \\
\hline$<60$ & Reference & & $<0.0001$ & & & & $<0.0001$ & \\
\hline $60-79$ & 0.92 & $0 \cdot 17$ & $<0.0001$ & $2 \cdot 5$ & $0 \cdot 85$ & $0 \cdot 22$ & 0.0001 & $2 \cdot 34$ \\
\hline $80+$ & 1.53 & $0 \cdot 18$ & $<0.0001$ & $4 \cdot 6$ & $1 \cdot 49$ & $0 \cdot 24$ & $<0.0001$ & $4 \cdot 43$ \\
\hline Shock - none & Reference & & $<0.0001$ & & & & 0.0363 & \\
\hline Tachycardia $(p>=100)$ & $0 \cdot 76$ & $0 \cdot 13$ & $<0.0001$ & $2 \cdot 15$ & 0.34 & $0 \cdot 18$ & 0.0570 & 1.40 \\
\hline $\mathrm{BP}<100$ & 0.89 & $0 \cdot 16$ & $<0.0001$ & $2 \cdot 43$ & 0.50 & 0.21 & 0.0199 & 1.65 \\
\hline $\mathrm{BP}<70$ & $1 \cdot 75$ & 0.30 & $<0.0001$ & $5 \cdot 60$ & 0.77 & 0.39 & 0.0517 & $2 \cdot 15$ \\
\hline $\mathrm{BP}<50$ & $2 \cdot 75$ & 0.43 & $<0.0001$ & $15 \cdot 69$ & 0.83 & 0.61 & $0 \cdot 1759$ & $2 \cdot 28$ \\
\hline \multicolumn{9}{|l|}{ Comorbidity } \\
\hline None & $-1 \cdot 04$ & $0 \cdot 16$ & $<0.0001$ & 0.35 & -1.06 & $0 \cdot 20$ & $<0.0001$ & 0.35 \\
\hline Cardiac failure & 0.72 & $0 \cdot 15$ & $<0.0001$ & $2 \cdot 06$ & 0.59 & $0 \cdot 21$ & 0.0051 & $1 \cdot 81$ \\
\hline Renal failure & 1.55 & $0 \cdot 21$ & $<0.0001$ & $4 \cdot 72$ & 1.68 & 0.29 & $<0.0001$ & $5 \cdot 40$ \\
\hline Liver failure & 1.04 & 0.22 & $<0.0001$ & $2 \cdot 84$ & & & NS & \\
\hline Disseminated malignancy & $1 \cdot 83$ & $0 \cdot 19$ & $<0.0001$ & $6 \cdot 22$ & 1.43 & $0 \cdot 28$ & $<0.0001$ & $4 \cdot 18$ \\
\hline Pneumonia & 0.92 & 0.29 & 0.0017 & $2 \cdot 50$ & & & NS & \\
\hline Malignancy & 0.59 & $0 \cdot 28$ & 0.0370 & $1 \cdot 80$ & & & NS & \\
\hline Haematological malignancy & $0 \cdot 76$ & $0 \cdot 28$ & 0.0061 & $2 \cdot 13$ & 0.77 & 0.35 & 0.0292 & $2 \cdot 15$ \\
\hline \multicolumn{9}{|l|}{ Diagnosis } \\
\hline No lesion identified, no SRH & & & & & Reference & & 0.0005 & \\
\hline No lesion identified, SRH present & & & & & $-0 \cdot 16$ & $0 \cdot 38$ & 0.6710 & 0.85 \\
\hline Peptic ulcer & & & & & $-0 \cdot 16$ & $0 \cdot 14$ & $0 \cdot 2549$ & $0 \cdot 85$ \\
\hline $\begin{array}{l}\text { Malignancy } \\
\text { Varices }\end{array}$ & & & & & $1 \cdot 14$ & 0.25 & $<0.0001$ & $3 \cdot 14$ \\
\hline Varices & & & & & $-0 \cdot 40$ & $0 \cdot 28$ & $0 \cdot 1419$ & 0.67 \\
\hline Mallory-Weiss & & & & & -0.33 & 0.47 & 0.4792 & 0.71 \\
\hline Erosive disease & & & & & $-0 \cdot 24$ & $0 \cdot 25$ & 0.3225 & 0.78 \\
\hline Oesophagitis & & & & & $0 \cdot 29$ & $0 \cdot 21$ & $0 \cdot 1685$ & 1.34 \\
\hline Other & & & & & -0.09 & $0 \cdot 28$ & 0.7589 & 0.91 \\
\hline Major SRH & & & & & $1 \cdot 05$ & $0 \cdot 17$ & $<0.0001$ & $2 \cdot 87$ \\
\hline Rebleeding & & & & & $1 \cdot 71$ & $0 \cdot 15$ & $<0.0001$ & $5 \cdot 57$ \\
\hline Constant $\left(\mathbf{B}_{0}\right)$ & $-1 \cdot 22$ & 0.13 & $<0.0001$ & & $-2 \cdot 98$ & $0 \cdot 24$ & $<0.0001$ & \\
\hline
\end{tabular}

$B$ represents the variable coefficient in the logistic regression equation and $B_{0}$ represents a constant. $S E$ is the standard error of the coefficient B. Significance is the statistical significance for the hypothesis that the coefficient is different from zero. $\operatorname{Exp}(B)$ represents the factor change in the odds that death will occur. For the categorised variables the value should only be interpreted within each variable. The prediction of mortality is calculated using the equation $p=\frac{1}{1+e^{-\left(B_{0}+B_{1} X_{1}+B_{2} X_{2}+B_{3} X_{3}+\ldots \ldots B_{p} X_{p}\right)}}$ where $p$ is the probability of death and $\mathrm{X}$ represents the variable, where $\mathrm{X}=0$ if absent and 1 if present. $\mathrm{SRH}=$ stigmata of recent haemorrhage, $\mathrm{NS}=$ not significant.

the log likelihood ratio test statistic was greater than $0 \cdot 1$. Confidence interval analysis was undertaken using CIA software. ${ }^{22}$

\section{Results}

Utilisation of all the principal risk factors that determine outcome necessitates the development of two related models. Important predictive variables such as diagnosis and the presence of stigmata of recent haemorrhage are usually only available once endoscopy has been performed. An initial predictive model has been developed based upon the information derived from the history, examination, and simple blood tests. A second more complete model includes, in addition, risk factors derived from endoscopic information and further haemorrhage.

Data were drawn from 4185 cases presenting with an acute upper gastrointestinal haemorrhage. Overall mortality was $14 \%$ (585 of $4142^{\star}$ ). Further haemorrhage (continued bleeding necessitating operation or rebleeding)

occurred in $18 \%$ (736) and was associated with a $37 \%$ (272 of $730^{\star}$ ) mortality. The initial model was based upon 3981 cases for whom all investigated variables were recorded. The second complete model was based upon 2956 cases that had, in addition, undergone diagnostic endoscopy or emergency surgery.

Table I lists the factors considered in this study with crude odds ratios and $95 \%$ confidence intervals. Continuous variables have been categorised.

Age, sex, comorbidity, shock, and haemoglobin had a crude odds ratio significantly different form 1 and were entered into a logistic regression analysis with death as the dependant variable. After forward stepwise analysis, 'sex' and 'haemoglobin $<10 \mathrm{~g} / \mathrm{dl}$ ' were excluded from the model.

Diagnosis, stigmata of recent haemorrhage, and rebleeding were then entered into a second analysis together with the significant variables from the first analysis.

Table II gives the B coefficients for both models with the standard error and significance. Age, shock, comorbidity, diagnosis, in a total of 43 cases and in six cases in the group sustaining furth

TABLE III Numerical risk scoring system

\begin{tabular}{|c|c|c|c|c|}
\hline \multirow[b]{2}{*}{ Variable } & \multicolumn{4}{|l|}{ Score } \\
\hline & 0 & 1 & 2 & 3 \\
\hline $\begin{array}{l}\text { Age } \\
\text { Shock }\end{array}$ & $\begin{array}{l}<60 \text { Years } \\
\text { 'No shock', systolic BP }>=100 \text {, } \\
\text { pulse }<100\end{array}$ & $\begin{array}{l}60-79 \text { Years } \\
\text { 'Tachycardia', systolic BP }>=100 \text {, } \\
\text { pulse }>=100\end{array}$ & $\begin{array}{l}>=80 \text { Years } \\
\text { 'Hypotension', systolic BP }<100\end{array}$ & \\
\hline Comorbidity & No major comorbidity & & $\begin{array}{l}\text { Cardiac failure, ischaemic heart disease, } \\
\text { any major comorbidity }\end{array}$ & $\begin{array}{l}\text { Renal failure, liver failure, } \\
\text { disseminated malignancy }\end{array}$ \\
\hline & $\begin{array}{l}\text { Mallory-Weiss tear, no lesion } \\
\text { identified and no SRH }\end{array}$ & All other diagnoses & Malignancy of upper GI tract & \\
\hline Major SRH & None or dark spot only & & $\begin{array}{l}\text { Blood in upper GI tract, adherent clot, } \\
\text { visible or spurting vessel }\end{array}$ & \\
\hline
\end{tabular}


stigmata of recent haemorrhage, and rebleeding are all independently significant factors in the prediction of mortality in these models.

A simple risk score has been devised using only these significant variables. An integer score was attributed to each category of each

TABLE IV(A) Observed mortality by initial risk score

\begin{tabular}{llcccccccc}
\hline Score & & 0 & 1 & 2 & 3 & 4 & 5 & 6 & 7 \\
\hline \multirow{4}{*}{ Deaths } & No & 595 & 505 & 641 & 890 & 859 & 326 & 141 & 24 \\
& $\%$ & 14.9 & 12.7 & $16 \cdot 1$ & $22 \cdot 4$ & $21 \cdot 6$ & $8 \cdot 2$ & 3.5 & 0.6 \\
& No & 1 & 12 & 36 & 98 & 211 & 129 & 69 & 12 \\
& $\%$ & 0.2 & $2 \cdot 4$ & 5.6 & 11.0 & $24 \cdot 6$ & 39.6 & 48.9 & $50 \cdot 0$ \\
\hline
\end{tabular}

TABLE IV(B) Observed rebleeding and mortality by complete risk score

\begin{tabular}{|c|c|c|c|c|c|c|c|c|c|c|}
\hline & 0 & 1 & 2 & 3 & 4 & 5 & 6 & 7 & $8+$ \\
\hline Score & No & 144 & 281 & 337 & & 528 & & & 267 & 190 \\
\hline Rebleed & $\begin{array}{l}\% \\
\text { No }\end{array}$ & $\begin{array}{l}4 \cdot 9 \\
7\end{array}$ & $\begin{array}{l}9 \cdot 5 \\
9\end{array}$ & $\begin{array}{l}11 \cdot 4 \\
18\end{array}$ & $\begin{array}{l}15 \cdot 0 \\
50\end{array}$ & $\begin{array}{l}17 \cdot 9 \\
76\end{array}$ & $\begin{array}{l}15.3 \\
83\end{array}$ & $\begin{array}{c}10 \cdot 6 \\
102\end{array}$ & $113^{9 \cdot 0}$ & $\begin{array}{r}6 \cdot 4 \\
101\end{array}$ \\
\hline & $\%$ & 4.9 & $3 \cdot 4$ & $5 \cdot 3$ & $11 \cdot 2$ & $14 \cdot 1$ & $24 \cdot 1$ & 32.9 & 43.8 & 41 . \\
\hline Deaths & No & 0 & 0 & 1 & 8 & 16 & 30 & 20 & 23 & 25 \\
\hline (no rebleed) & $\%$ & 0 & 0 & $0 \cdot 3$ & $2 \cdot 0$ & 3.5 & $8 \cdot 1$ & $9 \cdot 5$ & 14.9 & $28 \cdot 1$ \\
\hline Deaths & No & 0 & 0 & 0 & 5 & 12 & 19 & 34 & 49 & 53 \\
\hline (rebleed) & $\%$ & 0 & 0 & 0 & $10 \cdot 0$ & $15 \cdot 8$ & $22 \cdot 9$ & $33 \cdot 3$ & $43 \cdot 4$ & $52 \cdot 5$ \\
\hline Deaths & No & 0 & 0 & 1 & 13 & 28 & 49 & 54 & 72 & 78 \\
\hline (total) & $\%$ & 0 & 0 & $0 \cdot 2$ & $2 \cdot 9$ & $5 \cdot 3$ & $10 \cdot 8$ & $17 \cdot 3$ & $27 \cdot 0$ & 4 \\
\hline
\end{tabular}

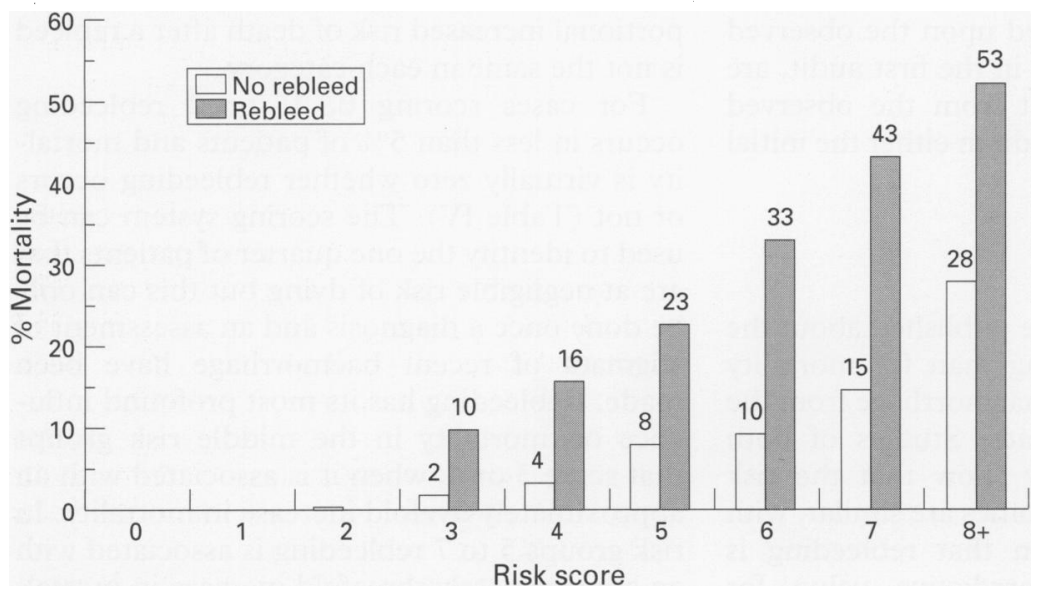

Figure 1: Mortality by risk score. variable according to its relative contribution in the logistic regression model (as determined by its regression coefficient). The score was then adapted so that the outcome in each category most closely fitted the predictions of the logistic regression model.

Age and degree of shock were categorised and each attributed a score of 0,1 , or 2 . Comorbidity was categorised and attributed a score of 0,2 , or 3 . This gives a maximum additive score of 7 before diagnosis.

A score of 0,1 , or 2 for diagnosis and 0 or 2 for stigmata of recent haemorrhage was then added to give a maximum score of 11 . Scores of 8 or more are considered as one category as there are very few cases in these very high risk categories. Table III shows the derived scoring system.

The population experiencing further haemorrhage is considered separately from the population without further haemorrhage in the complete model.

Table IV shows the observed mortality and rebleeding rate in each category for both models. Figure 1 shows these data for the complete model. Mortality increases in a stepwise fashion as the risk score increases. The rate of rebleeding also increases as the risk score increases. There were no deaths in categories 0 and 1 of the full model and only one death $(0.3 \%)$ in category 2 . Twenty six per cent of the sample were in these lowest three categories. The population that rebled experienced a fivefold increase in mortality in risk group 3, which decreased to a twofold increase for risk group 8.

\section{Validation}

Figure 2 shows the degree of association between the predictions of the full logistical regression model and the observed mortality in each category of the risk score. The box plots represent the distribution of predicted

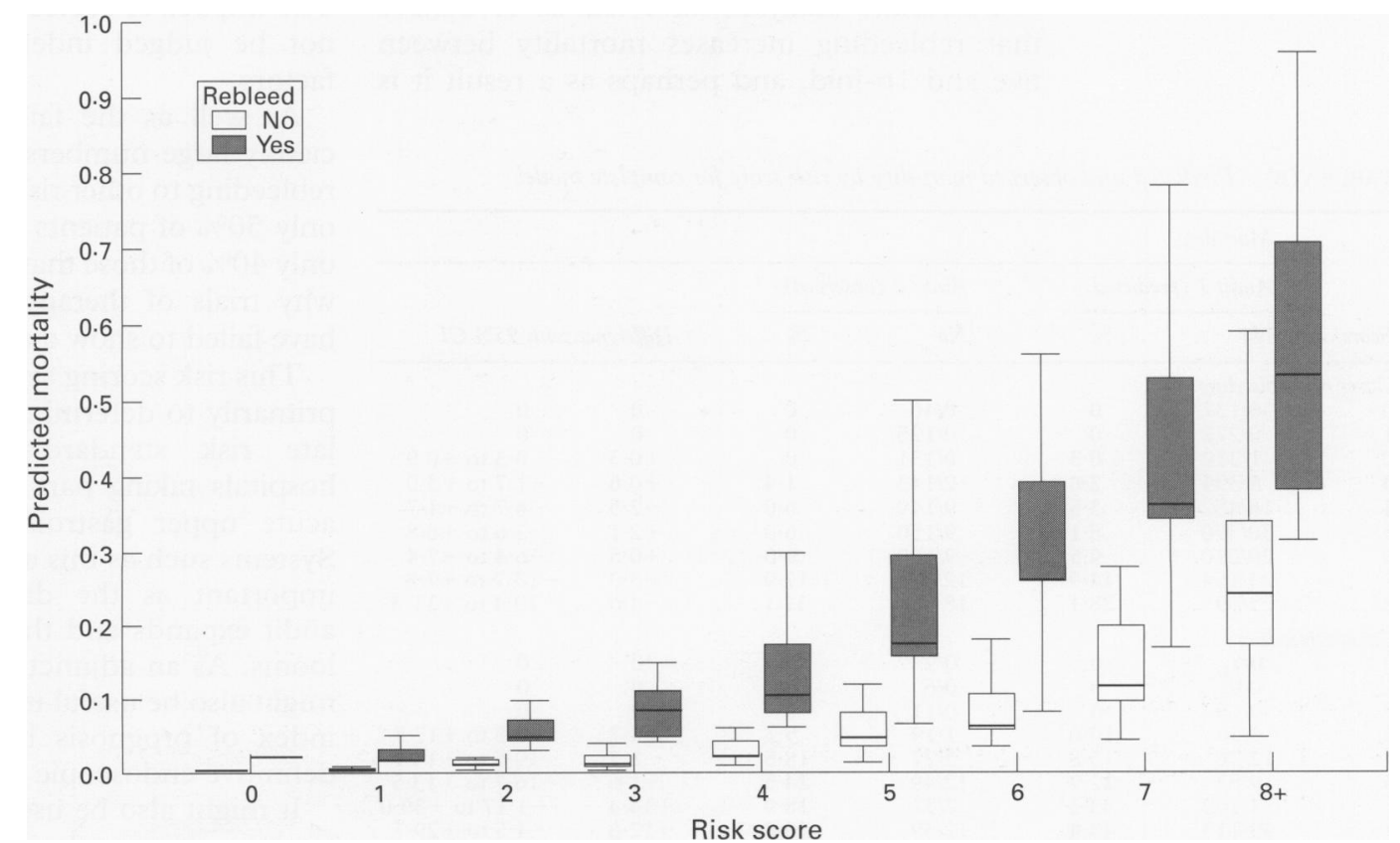

Figure 2: Boxplot of computer predicted mortality by risk score. 
TABLE V(A) Predicted and observed mortality by risk score for initial model

\begin{tabular}{|c|c|c|c|c|c|c|}
\hline \multirow{3}{*}{ Score } & \multicolumn{6}{|l|}{ Mortality } \\
\hline & \multicolumn{2}{|c|}{ Audit 1 (predicted) } & \multicolumn{2}{|c|}{ Audit 2 (observed) } & \multirow{2}{*}{\multicolumn{2}{|c|}{ Difference with $95 \%$ CI }} \\
\hline & No & $\%$ & No & $\%$ & & \\
\hline $\begin{array}{l}0 \\
1 \\
2 \\
3 \\
4 \\
5 \\
6 \\
7\end{array}$ & $\begin{array}{r}1 / 595 \\
12 / 505 \\
36 / 641 \\
98 / 890 \\
211 / 859 \\
129 / 326 \\
72 / 141 \\
12 / 24\end{array}$ & $\begin{array}{r}0 \cdot 2 \\
2 \cdot 4 \\
5 \cdot 6 \\
11 \cdot 0 \\
24 \cdot 6 \\
39 \cdot 6 \\
51 \cdot 1 \\
50 \cdot 0\end{array}$ & $\begin{array}{c}0 / 246 \\
6 / 201 \\
14 / 249 \\
38 / 311 \\
77 / 364 \\
47 / 134 \\
42 / 68 \\
6 / 8\end{array}$ & $\begin{array}{r}0 \cdot 0 \\
3 \cdot 0 \\
6 \cdot 1 \\
12 \cdot 1 \\
21 \cdot 0 \\
35 \cdot 1 \\
61 \cdot 8 \\
75 \cdot 0\end{array}$ & $\begin{array}{r}+0 \cdot 2 \\
-0 \cdot 6 \\
0 \cdot 0 \\
-1 \cdot 2 \\
+3 \cdot 4 \\
+4 \cdot 5 \\
-10 \cdot 7 \\
-25 \cdot 0\end{array}$ & $\begin{array}{l}-0.2 \text { to }+0.5 \\
-3.3 \text { to }+2.1 \\
-3.9 \text { to }+2.9 \\
-5.4 \text { to }+3.0 \\
-1.8 \text { to }+8.5 \\
-5.2 \text { to }+14 \cdot 2 \\
-24.9 \text { to }+3.5 \\
-61.1 \text { to }+11 \cdot 1\end{array}$ \\
\hline Total & $568 / 3981$ & $14 \cdot 3$ & . $230 / 1584$ & $14 \cdot 5$ & & \\
\hline
\end{tabular}

mortalities (using the logistic regression equation) for cases within each risk score category. It can be seen that there is a high degree of association between the predictions of the logistic regression model and the greatly simplified numerical score.

The risk score has been validated in a second population of 1625 cases collected using an identical methodology as part of the second phase of the National Audit. All the necessary variables were recorded in 1584 cases. In 1190 cases, variables for endoscopic diagnosis and stigmata of recent haemorrhage were also recorded. It can be seen in Table $\mathrm{V}$ that the predicted outcomes, based upon the observed outcome by risk category in the first audit, are not significantly different from the observed outcome in the second audit in either the initial or complete models.

\section{Discussion}

There is a great deal more published about the risk factors for rebleeding than for mortality after an acute episode of haemorrhage from the upper gastrointestinal tract. Studies of both rebleeding and mortality show that the risk factors for these two outcomes are similar, with the additional conclusion that rebleeding is itself of independent predictive value for mortality.

Univariate analyses have led us to believe that rebleeding increases mortality between five and 16-fold, and perhaps as a result it is

TABLE V(B) Predicted and observed mortality by risk score for complete model

\begin{tabular}{|c|c|c|c|c|c|c|}
\hline \multirow[b]{3}{*}{ Score } & \multicolumn{6}{|c|}{ Mortality } \\
\hline & \multicolumn{2}{|c|}{ Audit 1 (predicted) } & \multicolumn{2}{|c|}{ Audit 2 (observed) } & & \\
\hline & No & $\%$ & No & $\%$ & \multicolumn{2}{|c|}{ Difference with $95 \%$ CI } \\
\hline \multicolumn{7}{|c|}{ Cases not rebleeding } \\
\hline 0 & $0 / 137$ & 0 & $0 / 46$ & 0 & 0 & 0 \\
\hline 1 & $0 / 272$ & 0 & $0 / 125$ & 0 & 0 & 0 \\
\hline 2 & $1 / 319$ & $0 \cdot 3$ & $0 / 131$ & 0 & +0.3 & -0.3 to +0.9 \\
\hline 3 & $8 / 394$ & $2 \cdot 0$ & $2 / 143$ & $1 \cdot 4$ & +0.6 & -1.7 to +3.0 \\
\hline 4 & $16 / 452$ & $3 \cdot 5$ & $9 / 149$ & $6 \cdot 0$ & $-2 \cdot 5$ & -6.7 to +1.7 \\
\hline 5 & $30 / 370$ & $8 \cdot 1$ & $9 / 150$ & $6 \cdot 0$ & $+2 \cdot 1$ & $-2 \cdot 6$ to $+6 \cdot 8$ \\
\hline 6 & $20 / 210$ & $9 \cdot 5$ & $9 / 100$ & $9 \cdot 0$ & +0.5 & $-6 \cdot 4$ to $+7 \cdot 4$ \\
\hline 7 & $23 / 154$ & $14 \cdot 9$ & $12 / 67$ & $17 \cdot 9$ & $-3 \cdot 0$ & $-13 \cdot 7$ to $+7 \cdot 8$ \\
\hline $8+$ & $25 / 89$ & $28 \cdot 1$ & $18 / 56$ & $32 \cdot 1$ & $-4 \cdot 0$ & $-19 \cdot 4$ to $+11 \cdot 3$ \\
\hline \multicolumn{7}{|c|}{ Cases rebleeding } \\
\hline 0 & $0 / 7$ & 0 & $0 / 2$ & 0 & 0 & 0 \\
\hline 1 & $0 / 9$ & 0 & $0 / 6$ & 0 & 0 & 0 \\
\hline 2 & $0 / 18$ & 0 & $0 / 11$ & 0 & 0 & 0 \\
\hline 3 & $5 / 50$ & $10 \cdot 0$ & $1 / 19$ & $5 \cdot 3$ & $+4 \cdot 7$ & $-8 \cdot 3$ to $+17 \cdot 8$ \\
\hline 4 & $12 / 76$ & $15 \cdot 8$ & $5 / 27$ & $18 \cdot 5$ & $-2 \cdot 7$ & $-19 \cdot 5$ to $+14 \cdot 1$ \\
\hline 5 & $19 / 83$ & $22 \cdot 9$ & $12 / 49$ & $24 \cdot 5$ & -1.6 & -16.7 to +13.5 \\
\hline 6 & $34 / 102$ & $33 \cdot 3$ & $7 / 37$ & $18 \cdot 9$ & $+14 \cdot 4$ & -1.17 to $+30 \cdot 0$ \\
\hline 7 & $49 / 113$ & $43 \cdot 4$ & $12 / 39$ & $30 \cdot 8$ & $+12 \cdot 6$ & $-4 \cdot 5$ to $+29 \cdot 7$ \\
\hline $8+$ & $53 / 101$ & $52 \cdot 5$ & $18 / 33$ & $54 \cdot 5$ & $+2 \cdot 07$ & $-21 \cdot 7$ to $+17 \cdot 5$ \\
\hline
\end{tabular}

often regarded as the harbinger of death. Indeed the thrust of modern treatment is specifically targeted at preventing rebleeding by physical means in those lesions amenable to endoscopic haemostatic therapy in the belief that a reduction in mortality should follow. Although several clinical trials have shown a significant reduction in rebleeding with these methods, however, the reduction in mortality has been much more elusive and only two trials using lasers have shown a significant reduction in mortality. ${ }^{23}$ Meta-analysis has suggested a $30 \%$ improvement in mortality in the peptic ulcer group with visible vessels. ${ }^{24}$ Although rebleeding is a very important sign to detect and act upon, either endoscopically or surgically, there are many other factors that determine the final outcome.

Our scoring system has been developed with a view to simplicity and ease of variable acquisition. We have shown how it can be used to broadly categorise patients by risk and there are several important conclusions for the model: firstly, that the risk of rebleeding as well as the risk of death increases as the risk score increases; secondly, that patients who rebleed have an increased mortality compared with those who do not rebleed; thirdly, that the proportional increased risk of death after a rebleed is not the same in each category.

For cases scoring 0,1 , or 2 rebleeding occurs in less than $5 \%$ of patients and mortality is virtually zero whether rebleeding occurs or not (Table IV). The scoring system can be used to identify the one quarter of patients that are at negligible risk of dying but this can only be done once a diagnosis and an assessment of stigmata of recent haemorrhage have been made. Rebleeding has its most profound influence on mortality in the middle risk groups that score 3 or 4 , when it is associated with an approximately fivefold increase in mortality. In risk groups 5 to 7 rebleeding is associated with an approximately threefold increase in mortality and for risk group 8, a twofold increase. The impact of rebleeding on outcome should not be judged independently of other risk factors.

As well as the failure to investigate sufficiently large numbers of cases, the relation of rebleeding to other risk factors and the fact that only $50 \%$ of patients that die have rebled and only $40 \%$ of those that rebleed die, may explain why trials of therapy that reduce rebleeding have failed to show a reduction in mortality.

This risk scoring system has been developed primarily to determine case mix and to calculate risk standardised mortality for the hospitals taking part in the national audit of acute upper gastrointestinal haemorrhage. ${ }^{25}$ Systems such as this are likely to become more important as the discipline of comparative audit expands and the threat of league tables looms. As an adjunct to clinical judgement, it might also be useful in the clinical setting as an index of prognosis both before and after a definitive endoscopic diagnosis.

It might also be used in the development of treatment protocols. The full array of management tools for optimal care of patients with 
upper gastrointestinal haemorrhage is expensive. Rapid endoscopy by experienced endoscopists on call 24 hours per day, high dependency units, medicosurgical collaboration, and on call endoscopy staff all have considerable financial implications. Being able to select patients that will benefit the most from intensive treatment is one important step in the rationalisation of resources. Early discharge or even outpatient treatment of very low risk groups or the transfer to intensive care facilities of very high risk cases for whom a determined effort to save life is being made, might easily be incorporated into a treatment protocol, however, the use of such a system in selecting patients for surgery could only be promoted after evidence from clinical trials.

It is important to understand that this system, like most predictive methods cannot predict the outcome of any individual patient, except perhaps those in categories 0 and 1 in whom no deaths occurred. The risk of death is simply a measurement of the number of deaths that might be expected in a large population of cases with those risk factors. The testing of the model in a second large population has, however, allowed us to confirm the general applicability of the model based upon current standards of treatment.

This project was undertaken under the auspices of the Royal College of Physicians of London, the Royal College of Surgeons of England, the British Society of Gastroenterology, and the Association of Surgeons of Great Britain and Ireland. We gratefully acknowledge the financial support of Lederle Pharmaceuticals and the support of South West Thames, North West Thames, and Trent regional health authorities and the West Midlands Gastroenterology services committee. We also acknowledge the great deal of work performed by medical and audit staff in each of the participating units.

Members of the steering group: Professor T C Northfield (Chairman), St George's Hospital Medical School, London; Mr H B Devlin (Director), Surgical Epidemiology and Audit Mr H B Devlin (Director), Surgical Epidemiology and Audit
Unit, RCS, London; Dr R F A Logan, Queen's Medical Unit, RCS, London; Dr R F A Logan, Queen's Medical
Centre, Nottingham; Dr J Levi, Northwick Park Hospital, Centre, Nottingham; Dr J Levi, Northwick Park Hospital,
London; Dr K Bardhan, Rotherham District General Hospital, London; Dr K Bardhan, Rotherham District General Hospital,
Rotherham; Dr A Hamlyn, Wordsley Hospital, Wordsley; Mr $\mathrm{G}$ Gillespie, Victoria Infirmary, Glasgow; $\mathrm{Mr} \mathrm{R}$ McCloy, Manchester Royal Infirmary, Manchester; Mr D Watkin, Leicester Royal Infirmary, Leicester; Mr M Crisp, Lederle Pharmaceuticals. Also Mr R Leicester (chairman) and Mrs C Romaya (administrator) of the British Society of Gastroenterology audit committee.

1 Rockall TA, Logan RFA, Devlin HB, Northfield TC. Incidence of and mortality from acute upper gastrointestinal haemorrhage in the UK. BMF 1995; 311: 222-6.
2 Swain CP, Kirham JS, Salmon PR, Bown SG, Northfield TC. Controlled trial of Nd-YAG laser photocoagulation in bleeding peptic ulcers. Lancet 1986; i: 1113.

3 Storey DW, Bown SG, Swain CP, Salmon PR, Kirkham JS, Northfield TC. Endoscopic prediction of recurrent bleeding in peptic ulcers. N Engl f Med 1981; 305: 915.

4 Northfield TC. Factors predisposing to recurrent haemorrhage after acute gastrointestinal bleeding. BMF 1971; 1: rhage

5 Katschinski BD, Logan RFA, Davies J, Langman MJS. Audit of mortality in upper gastrointestinal bleeding. Postgrad Med f 1989; 65: 913.

6 Katschinski B, Logan R, Davies J, Faulkner G, Pearson J, Langman $M$. Prognostic factors in upper gastrointestinal bleeding. Dig Dis Sci 1994; 39: 706.

7 Jones PF, Johnston SJ, McEwan AB, Kyle J, Needham CD. Further haemorrhage after admission to hospital for gastrointestinal haemorrhage. BMF 1973; 3: 660 .

8 Hunt PS. Mortality in patients with haematemesis and melaena: a prospective study. $B M F$ 1979; 1: 1238 .

9 Griffiths WJ. The visible vessel as an indicator of uncontrolled or recurrent gastrointestinal bleeding. $N$ Engl $f$ Med 1979; 300: 1411 .

10 Kalabakas A, Xourgias B, Karamanolis D. Incidence and significance of stigmata of recent haemorrhage in ulcer patients without clinical evidence of recent bleeding. Gut 1990; 31: A1206.

11 Wara P, Berg V, Amdrup E. Factors influencing mortality in patients with bleeding ulcer. A review of 7 years experience preceding therapeutic endoscopy. Acta Chir Scand 1983; 149: 775 .

12 Macleod IA, Mills PR. Factors identifying the probability of further haemorrhage after acute upper gastrointestinal haemorrhage. Br $\mathcal{J}$ Surg 1982; 69: 256.

13 Bornman PC, Theodorou NA, Shuttleworth RD, Essel HP, Marks IN. Importance of hypovolaemic shock and endoscopic signs in predicting recurrent haemorrhage from peptic ulceration: a prospective evaluation. BMf 1985; 291 (27 July): 245

14 Branicki FJ, Coleman SY, Fok PJ, Pritchett CJ, Fan S, Lai ECS, et al. Bleeding peptic ulcer: a prospective evaluation of risk factors for rebleeding and mortality. World $\mathcal{f}$ Surg 1990; 14: 262 .

15 Clason AE, Macleod DAD, Elton RA. Clinical factors in the prediction of further haemorrhage or mortality in acute upper gastrointestinal haemorrhage. Br f Surg 1986; 73: 985 .

16 Morgan AG, Clamp SE. OMGE International Upper Gastrointestinal Bleeding Survey 1978-1982. Scand $\mathcal{f}$ Gastrointestinal Bleeding Survey 1978-1982

17 Thomas GE, Cotton PB, Clark CG, Boulos PB. Survey of management in acute upper gastrointestinal haemorrhage. f Roy Soc Med 1980; 73: 90.

18 Emberton M, Meredith P. Caught in the act. British fournal of Healthcare Computing and Information Management 1993; 10: 32 .

19 Emberton M, Rockall TA, Meredith P. Scanning for Audit. British fournal of Healthcare Computing and Information Management 1994; 11: 23.

20 Hall GH, Round AP. Logistic regression - explanation and use. $\mathcal{F}$ R Coll Physicians Lond 1994; 28 (3): 242.

21 SPSS. Advanced statistics. 6.0.1 ed. Chicago: SPSS Inc, 1993.

22 Gardner MJ, Altman DG. Statistics with confidence - confidence intervals and statistical guidelines. London: BMJ Publishing Group, 1989.

23 Steele RJC. Endoscopic haemostasis for non-variceal upper gastrointestinal haemorrhage. Br f Surg 1989; 76: 219-25.

24 Sacks HS, Chalmers TC, Blum AL, Berrier J, Pagano D. Endoscopic haemostasis. An effective therapy for bleeding peptic ulcers. $¥ A M A 1990 ; 264$ : 494-9.

25 Variation in outcome after acute upper gastrointestinal haemorrhage. Lancet 1995; 346: 346-50. 